\title{
水流流速測定に用いる光学的手法の改良
}

\section{Improvements in Optical Velocity Measurements for Water Flow}

\author{
北海道大学工学部 正 会 員 吉田 静男 \\ 学生会員 塚田 昌司
}

\section{1.はじめに}

最近、水流の観測に光学的手法が導入される傾向にある。その内、一つは、古くから用いられている流れ の可視化法で、他は、LDV (Laser Doppler Velocimeter) 等、レーザーを用いた計測法の応用である。 こうした光学的手法は、将来、水質の点観測という、待望の技法を生む可能性も有しており、水理研究に必 要な測定技術の今後には明るい見通しがある。従って、時とともに、この種の手法の導入が盛んになること は確実と考えられるが、そこには、1つの問題が存在する。それは、これらの技法は、あまりに汎用性に富 み、どの様な分野でも一応の機能は発揮されるが、必らずしも、個々の分野に最適で導入し易いものとはな っていないということである。本研究は、この事実に着目し、水理学的研究に関与する立場から従来の光学 的手法の改良を試みたものである。

\section{2. 流れの可視化法に関する一エ夫}

可視化法の利点は、透明な媒質の流れの一部、あるいは、全体の観察を可能にさせることにあるといえる が、単に色素を流水中に流すだけでは、3 次元的な色素の分布によって、かえって観察の障害になることも ある。たとえば、サイクロイド波形の界面波直下の流れ音を広い光束で照明したならば、一様に色素が広が って見え、スパイラル渦の存在は確められないが、光束をスリット状にするとこれを確めることができる。 この様に既存の可視化法を単に受け入れるだけでは、重大な見落しをする可能性があり、大いに、注意を払 う必要がある。又、既存の手法は、一般に、沉用性はあっても、個々の流れ構造を可視化する上に最適とは いい難く、研究者自ら工夫を重ねてゆく必要がある。

ここに紹介する可視化法は、筆者の一人が過去に用いた、ウラニンを塗布した糸を流水中に張って色素を 溶出させる方法 ${ }^{2)}$ を改良したものと光束形状に工夫のある照明法から成っている。この方法を用いると、弱 い乱れを有する流れの 3 次元構造や 3 次元構造の界面波の観測が可能である。装置の概要は図 -1 に示すと おりで、いずれの部分も容易に手に入るか、簡単に製作可能なものばかりである。実際に糸を流れに垂直、 且、水平に導くと写真一1の模様が観測できる。なお、長時間観測を続ける場合には糸を連続的に流水中に 送り込むと良い。この色素流出部を製作する上で注意すべき点は(1)不必要な流体空間が着色しない様パイプ で被う(2)ビーズ等を用いて屈折部での系の運びをよくする(3)糸の移動は、できるだけ、一定速度でゆっくり と行なう、等であり、特に困難な点はない。次に照明部について述べると、要するにプロジェクターであっ て、工夫は光束の形状を変えるスライドにのみなされている。スライドとしては図ー 2 に示す種々のメッシ ユやスリットのものを製作しておき、観測したい場面に応じて取り替えるとよい。たとえば、写真一 1 の観 測はスライド無しの広い光束で行なえるが、この写真では立体観がなく、色素の変移量の解析が行なえない。 このとき、スリット光束用スライドを用いると 2 次元の、又、メッシュ光束用スライドを用いると 3 次元の 解析が可能となる。写真一 2 は、メッシュ光束用スライドを用いて写真- 1 と同様の場面を撮映したもので ある。この照明法の最大の利点は、ただ単に、像の立体観を増すだけでなく、色素の位置座標が決定できる ところにある。このメッシュ光束法と似た方法として、従来、水素気泡法の中のタイムライン法とキンク法 を組合わせた手法 ${ }^{3)}$ があるが、この手法では気泡の3 次元的な位置座標を決定できないという欠点があった。 ここに紹介した照明法を実行するにあたり留意すべき点は1色素の吸収する光の波長を多く含む光源、たと 
えば、ウラニンに対してはキセノンランプ、等を使用する(2)観察や像の撮映は色素の発する光の波長だけ通 過させるフィルターを介して行なう(3)現象のスケールに合った間隔のメッシュを選ぶ(4)色素位置の決定にあ たっては、プロジェクターから出る光束が非平行であることを考虑する、等であり、特に、困難な点は無い。

\section{3. 素子型LDV}

1964年Yeh とCumminsは、現在では定着した LDV (Laser Doppler Velocimeter) の原理で、運動 する粒子の速度を測定できることを発表した。以来、L D Vに関する 100 編を越す多くの論文が発表され、

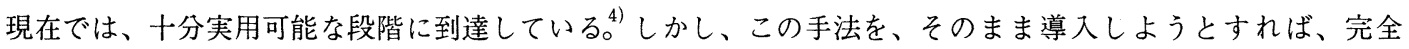
非接触型であるために、次の様な問題を生ずる。

(1)野外では勿論、実験水槽であっても大規模な流れを取扱う場合が多く、非接触測定を旨とする従来の光 学系は使用出来ないことが多い。あえてこれを行なおうとすれば側壁を透明な材質で作り替えたり、高価な 高出カレーザー光源を必要とする。なお、側壁の材質については規模の小さい流れであっても考慮が必要で ある。

(2)規模の小さい水流実験の場合でも、濁水の場合には光の減衰をまねき測定不可能となることがある。

(3)遠隔地又は深い位置での流速測定ができない。

(4)界面波近傍の流速測定は、光の屈折のため、ヘテロダイン検波法が不可能となる場合が多い。 ここに紹介する素子型L D Vは、いわば準非接触夕イプであり上記の問題をある程度解決できる。光学系、 及び、信号処理のブロックダイヤグラムは図ー 3 に示すとおりで、同図破線内の詳細は図ー4に示されてい る。なお、レンズ系の焦点距離は $6 \mathrm{~mm}$ 、実効レンズ径は $3 \mathrm{~mm}$ 、素子の直径は $5 \mathrm{~mm}$ で、プリズムから集光点ま での距離は $21 \mathrm{~mm}$ である。本素子の特徵は光源からレンズ系までの光路と散乱光の採取にファイバーを使用し、 光の減衰を防いでいる点にある。使用ファイバーの特性はGraded Index Type, Multimode Fiber (core 50 $\mu \mathrm{m} \operatorname{clad} 150 \mu \mathrm{m}) 、$ 損失 $3.0 \mathrm{~dB} / \mathrm{km}$ 、伝送帯域 $500 \mathrm{MHz} \cdot \mathrm{km}$ である。

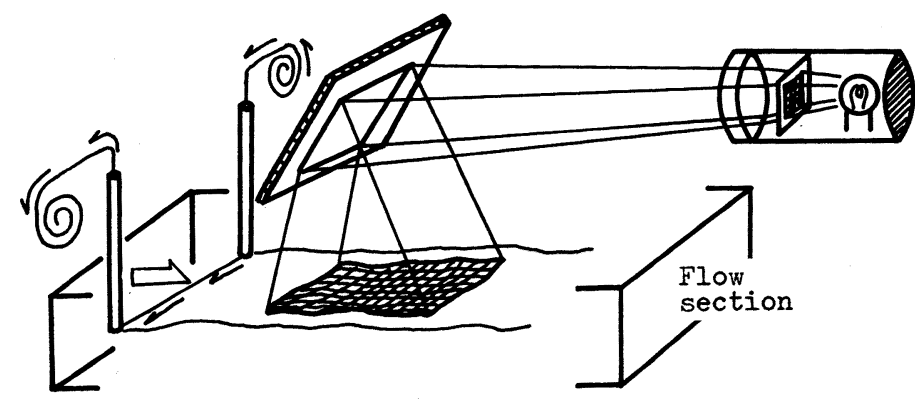

図-1
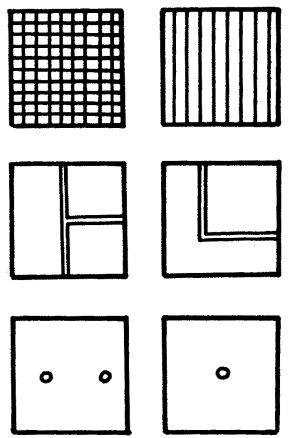

図-2
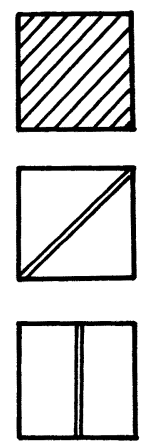

$$
2
$$

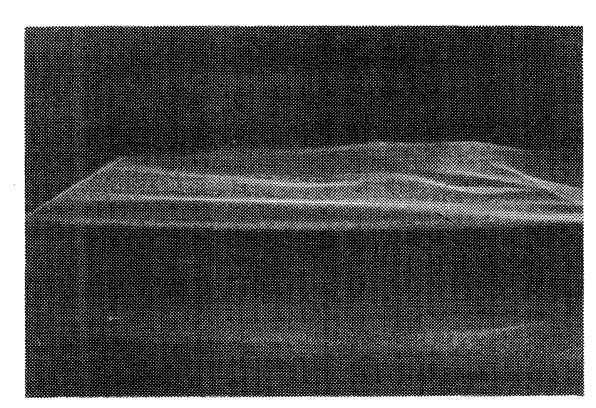

写真 -1

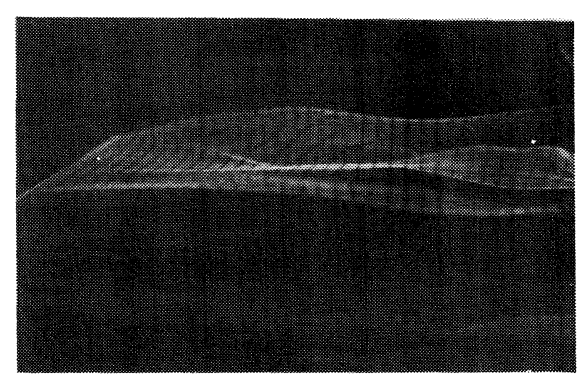

写真 -2 


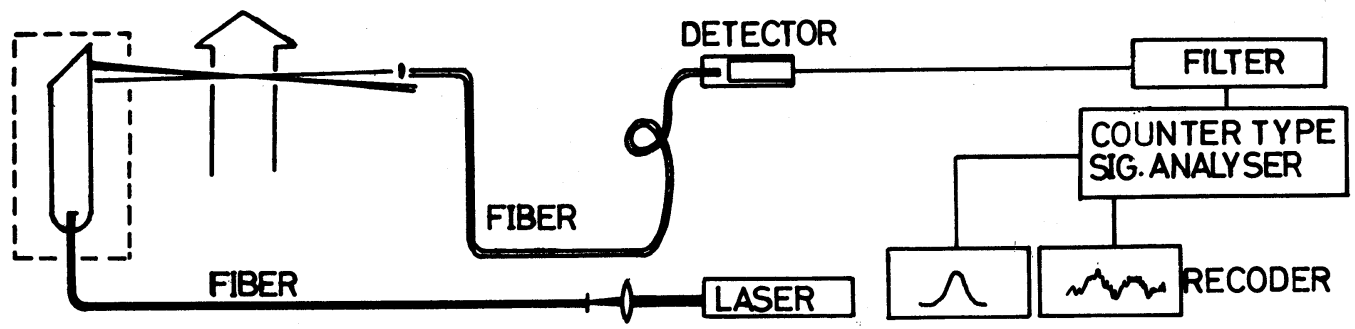

図-3

本素子にはもう一つの特徴がある。それはレンズ系を 通過した光束が図ー 5 に示す 3 つのピンホールにより 3 つの光束にわけられる点である。各ピンホールはレンズ 中心から等距離にあるから、レンズ系焦点で互いに交差 する。さらに、ピンホールを結んでできる三角形を直角 二等辺三角形になる様にし、二辺が直交する頂点に位置 するピンホール径を他の 5 倍程度に選定すると参照光法 で 2 方向の流速が測定可能となる。ここで直交する辺の

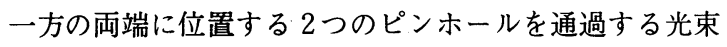
による一方向流速の測定原理を示しておく。今、流速べ クトルを $\mathrm{V}$ とし、2つの光束との、関係を示すと図ー 6 となる。なお、光学系の光軸と直交する方向の流速を $v$ とし $\mathbf{k}_{1} 、 \mathbf{k}_{2}$ は $2 つ の$ 光束が会合微少領域で固体微粒子 によって散乱されドップラー効果を受けた光と、それを 受けていない参照光の波数べクトルとする。図ー6では 直径の小さいピンホール（直径 $0.07 \mathrm{~mm}$ 程度）を参照光 としており $\mathbf{k}_{1}$ と $\mathbf{k}_{2}$ の強度はほぼ同じである。従って、 ヘテロダイン検波が可能となるが、このときDetector で検出される光強度は

$$
\mathrm{I} \propto \mathrm{A}_{1}{ }^{2}+\mathrm{A}_{2}{ }^{2}+2 \mathrm{~A}_{1} \mathrm{~A}_{2} \cos \left\{\left(\mathbf{k}_{2}-\mathbf{k}_{1}\right) \mathrm{Vt}+\varphi\right\}
$$

ここに $A_{1} 、 A_{2}$ は $\mathbf{k}_{1} 、 \mathbf{k}_{2}$ 光の振幅であり、右辺第 $1 、 2$ 項は直流成分を表わしている。又、第 3 項はビート信号 にもとずくものでこの周波数

$$
f_{\mathrm{d}}=\left(\mathbf{k}_{2}-\mathbf{k}_{1}\right) \mathbf{V} / 2 \pi
$$

を測定すれば流速 $v$ は次式によって求め得る。

$$
v=f_{\mathrm{d}} \lambda /(2 \mathrm{n} \sin \theta / 2)
$$

ここに入は真空中での光の波長、 $\mathrm{n}$ は媒質の屈折率、 $\theta$ は光軸と参照光のなす角である。たた、(1)から分か るとおり、 $f_{\mathrm{d}}$ の正負によって I に区別がない故、流向 の判定はできない。図一 7 は二層流界面から上方 1.0

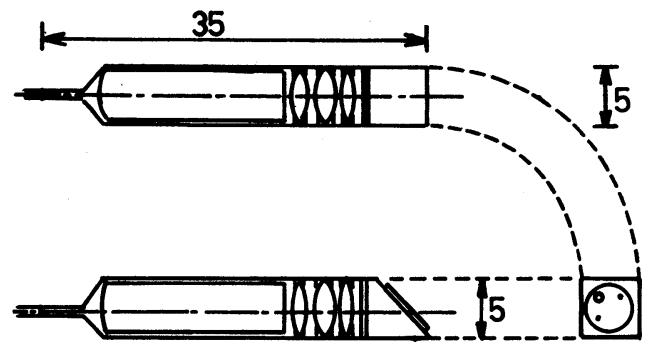

図- 4

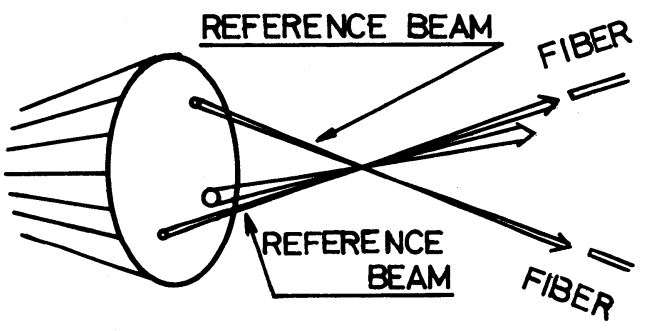

図- 5

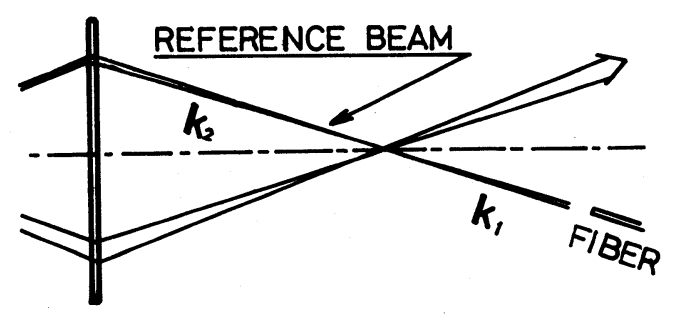

図-6

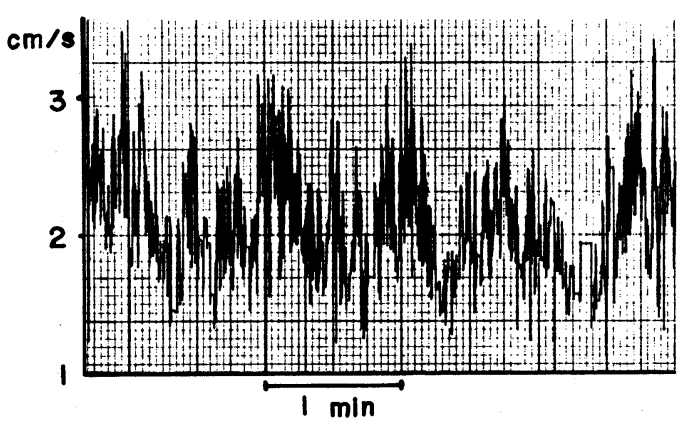

図-7 
$\mathrm{cm}$ における $f_{\mathrm{d}}$ カウンタータイプ信号処理器で測定し、そのアナログ出力を記録したものである。

本素子を用いると、先に述べた諸問題のうち(1) (3)がほぼ解決する。たとえば、1 $\mathrm{km}$ 離れた位置の流速で あっても、 $5 \mathrm{~mW}$ 程度のレーザー光源を用いれば、問題なく、測定可能と思われ、濁水であっても、河川の洪 水程度であれば、やはり、測定は可能である。又、2つの流速成分が同時に測定できる点も大きな特徴とい え、使用上、従来の熱線流速計に近い手軽さを保証できる。ただ、(4)の問題については、未だ、完全な解決 に至っておらず、今後、素子型L D V の一層の小型化をはかってゆく必要がある。又、今回使用のファイバ 一はマルチモードであり、ファイバー自身の振動があるとそのモードまで検出されるという不都合がある故、 できれば（多少高価犬゙が）シングルモードファイバーに切替え、この問題を本質的に解決するのが望ましい。

\section{Rizzo-HalliWell型LDVの試作及びその性能}

すでに述べた様に、二つの光束に分け、再度、会合させる手法をとる光学系を用いる限り、流向は検出で きない。流向は、静止媒質に対しても $f_{\mathrm{d}}$ が有限の值をとる様二つの光束間の周波数を変えることにより検出 できる。かりに、この周波数差を $f_{0}$ とすると、流速は次式で与えられる。

$$
v=\left(f_{\mathrm{d}}-f_{0}\right) \lambda /(2 \mathrm{n} \sin \theta / 2)
$$

ここで $f_{\mathrm{d}}$ は(2)式の場合同様 Defectorにより検出された光強度の変化周 波数である。従って、 $f_{\mathrm{d}}=f_{0}$ で $v=0 、 f_{\mathrm{d}}>f_{0}$ なら $v>0 、 0<f_{\mathrm{d}}<f_{0}$

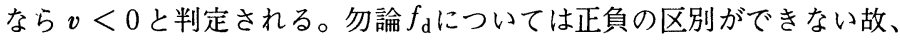
$f_{\mathrm{d}}<0$ 、すなわち $v_{0}$ を越える逆流流速がある場合には、再び流向の判 定が不可能となる。なお、これら $v 、 f_{\mathrm{d}} 、 f_{0}$ 間の関係は図ー 8 に示され ている。

上記の $f_{0}$ を作り出す方法としては、超音波によって作られる位相格子 をBragg cellとして使用する方法、複屈折素子を用いる方法、回析格

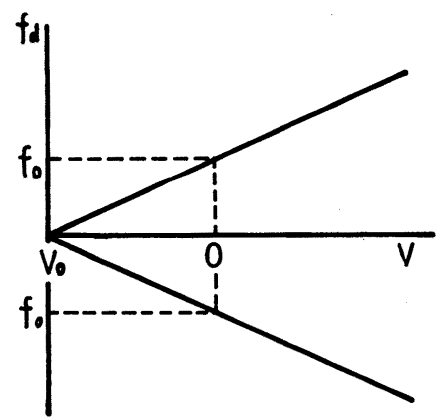

図-8 子を円筒の周辺にはりつけこれを回転させる方法 ${ }^{5}$ 等がある。しかし、いずれも簡単に試作できないか、高価 なものばかりで容易に導入し難い。

ここに紹介する Rizzo-Halliwell ${ }^{6)}$ による光学系は安価な材料で試作可能である。ただ、彼らの論文には原 理的なものしか書かれておらず、具体的な製法は不明である。従って、本論文には、筆者らが、彼らの基本 原理のみを採用して試作した光学系をできる限り詳細に示すとともに、その性能について記述する。

試作された光学系、及び、処理装置のブロック図は図ー9に示されている。又、写真－3は、この内の光 学系を示したものである。最も肝要な光周波数シフターは厚さ $1.0 \mathrm{~mm}$ 、直径 $30 \mathrm{~mm}$ の透明ガラス円板に固体 微粒子を一様に塗布し、この円板を小型モーター軸に取り付けたものから成り、特別な工夫は無い。周波数

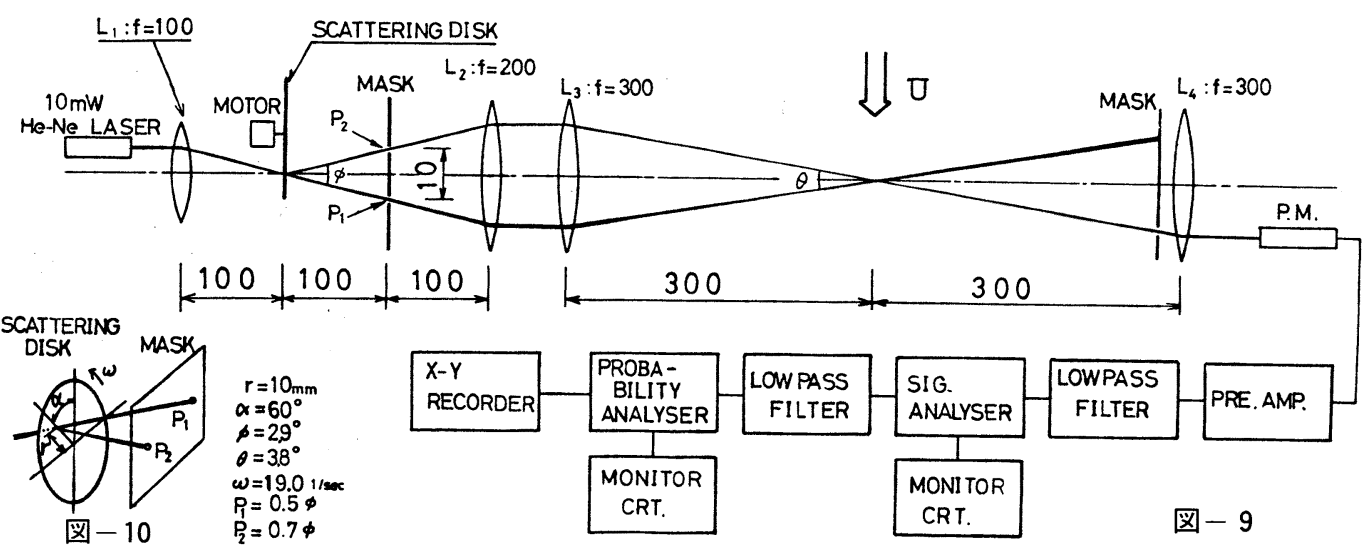


シフターで四方に散乱される光の周波数偏移量 $f_{0}$ は、 図ー10に定義される諸量㹸使用して、次式で表わされる。

$$
f_{0}=\omega \mathrm{r} \cos \alpha(2 / \lambda) \sin (\phi / 2)
$$

この $f_{0}$ が(4)式の $f_{0}$ に相当している。図一 9 に示した様 に散乱板後方にはピンホール（直径 $0.7 \mathrm{~mm}$ ) が $2 つ$ り、その 1つには偏移を受けない、パワーの大きい光 束 $\mathrm{B}_{1}$ が、他の 1 つには散乱光が導かれて参照光 $\mathrm{B}_{2}$ と なる。これら2つの光束はその後レンズ系により集光

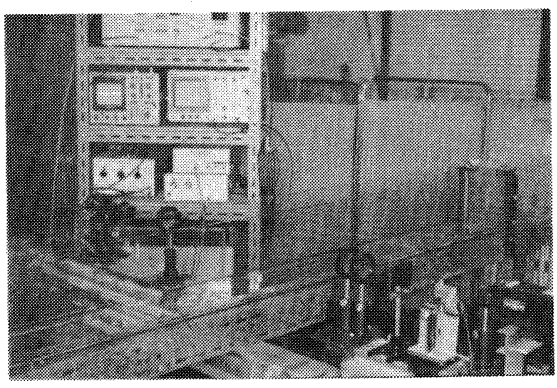

写真 -3 され会合する。この会合部が被測定部であり、ここを通過する固体粒子によって $\mathrm{B}_{1}$ の一部が散乱される。こ の散乱光の内、参照光 $\mathrm{B}_{2}$ と同一方向の光強度は、 $\mathrm{B}_{2}$ と同じ程度となる様にシフター円板上の固体粒子数を 分布させているので、最終的にDetector で検出される光強度の変動周波数 $f_{\mathrm{d}}$ は、シフターによる偏移周波数 と被測定部でのドップラー効果による偏移周波数との和となる。ここで検出光を処理した結果を見てみる。 まず、媒質が静止状態にある場合の $f_{\mathrm{d}} つ ま り ~ f_{0}$ に対応する電圧波形を示すと写真一 4 となる。この出力を力 ウンタータイプ信号処理器に導きそのアナログ出力を見ると、ある一定值を中心として変動する電圧值を得 る。この電圧変動は、シフター円板の回転軸と光軸の不一致によるもので、モーター回転数に比例した周期 を有している。この状態のまま流速を測定すると乱流の測定は正しく行えないものの平均流速の測定は可能 である。たとえば、上記アナログ出力をローパスフィルターに導けばよい。実際に図ー11に示す、水路床に 置かれた角柱後方の平均流速分布を測定してみよう。 $2 \mathrm{~Hz}$ 以下の低周波信号をプロバビリティアナライザーに 導くと、各測定位置での確率密度関数を図ー12のごとく得る。そこで確率密度関数のピークに対応する流速 を致みとり分布を描くと四ー11の実線となる。この分布から得る逆流領域は可視化観測によって求められる 逆流領域とほぼ一致する。

かくしてRizzo-Halliwell型L D V (移動拡散板による方法ともいう)によって流向を含む流速の測定が可 能であることが明らかとなったが、この装置では素子型L D V 同様のピンホールを用意することにより 2 次 元の流速を同時に測定することも可能である。最後にこれまでに記述してこなかった製作上、あるいは精度 上の幾つかの点を指摘しておこう。

(1)光源 レーザー光源のパワーの選定は媒質の透明度に依存する。通常の水道水で流路幅が $5 \mathrm{~cm}$ 程度で あれば $1 \mathrm{~mW}$ 程度で十分であろう。ただ、水道水のみでは透明度が良すぎるため散乱光が弱く、関東ロームを 少し流す等、散乱体を増やすことが必要となろう。なお、図一 12 は、 $10 \mathrm{~mW}$ の $\mathrm{He}-\mathrm{Ne}$ レーザー光源を使用し て得たが、水路幅が $15 \mathrm{~cm}$ あるため、やはり、関東ロームを少し流して散乱強度を高めている。

(2)ピンホールピンホールについてはその径の大きさと、ピンホール間隔の取り方に留意すべき点があ る。今回試作したピンホールは直径が $0.7 \mathrm{~mm}$ であ り、散乱円板とピンホール間の距離は $100 \mathrm{~mm}$ で あるから $f_{0}$ には最大 \pm 0.0035 程度の誤差を含むこ とを知る必要がある。このことは、ピンホール径 が小さい程精度は向上することを示しているが、 現実には光源のパワーの増強も必要となる。一方、 ピンホール間隔は(5)式の фに関係し、 $f_{0}$ を決定づ ける。かりに逆流流速が小さければ、申を小さくと ることができ、強い参照光を利用することができ る。なお、これまでふれてこなかったDetectorの 前のピンホールは、いわばマスクであり、関係の

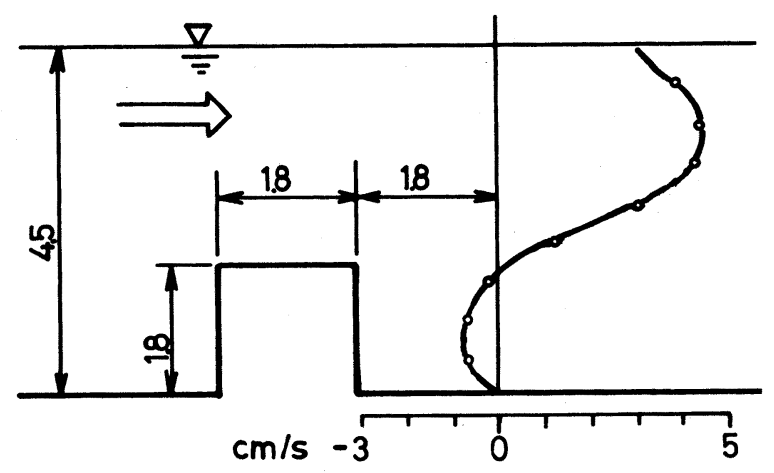

図 -11 
ない信号が検出されないためにも欠かせない。このピ ンホール径も小さい程よいが、要は光強度との関連で 決定される。

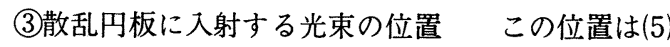
式の $\mathrm{r}$ とに関係し、申同様 $f_{0}$ を決定づける。光束はレ ンズで絞られているから一応点と見なしても、 $\mathrm{r}$ の測 定において約 $0.1 \mathrm{~mm}$ の誤差は見込まれる。 $\alpha$ につい てはその倍程度の誤差を見込む必要がある。ただこれ

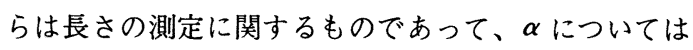
さらに別の要因による誤差も考える必要がある。すな わち $f_{0}$ をさくしようとして $\alpha$ なさく選ぶとビート 信号とペデスタルの区別が困難になるため測定誤差は 大きくなる。従って、 $\alpha$ はあまり小さくとらない方が 良い。

(4) $f_{0}$ の設定 $f_{0}$ をあまり大きくとると処理器の分 解能を必らず越してしまう。そこで、極力 $f_{0}$ を小く 設定する努力をする必要が生じるが、そのためには、 シフターの精度の向上も同時に行なわなくてはならな い。シフターの精度に関係する最も重要な点は $\omega に$ かわるモーターの回転むらをおさえ、散乱円板軸とモ ーター回転軸をできるだけ一致させることであるが、 乱流計測をも行ない得るほどの精度を得ようとするな らこの部分だけは専門の技術者に製作してもらうのが 賢明であろう。それでも精度が不十分という場合には 高価な他のシフターを導入する以外に道はないであろう。

(5)測定精度上記の様に測定精度にかかわる要因 は決して少なくない。たた、今回試作した L D V につ いては、むしろ使用した処理器の分解能が測定精度の 決定要因となっている。具体的に図一12の測定におけ る精度を示すと、フルスケールに対して約 $1 \mathrm{~mm} / \mathrm{s}$ の 程度である。

\section{文献}

1 ) 吉田静男: 密度界面における混合機構の研究, 土木学会論文報 告集, 273号, pp. 59 68, 1978.

2 ) 柏村正和 ·吉田静男 : 河口の流れの構造(1), 第15回海岸工学講 演会講演集, pp. 191〜194, 1968.

3 ) 浅沼強編：「流れの可視化ハンドブック」pp. 1〜377, 1977.

4 ) 三品博達・朝倉利光 : 光へテロダイン検出法の計測への応用一 ドップラー速度計を中心に一, 応用物理, Vol. 42, No. 6,1973.

5) 4 ) に同じ

6) Rizzo, J. E. \& N. A. Halliwell : Multicomponent frequency shifting self-aligning laser velocimeters, Rev.Sci.Instrum. 49 (8), Aug. 1978

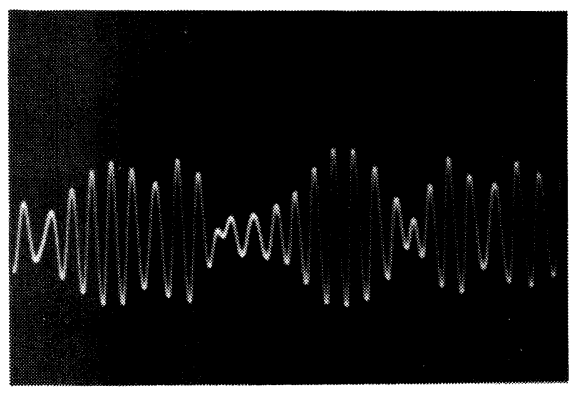

写真 -4
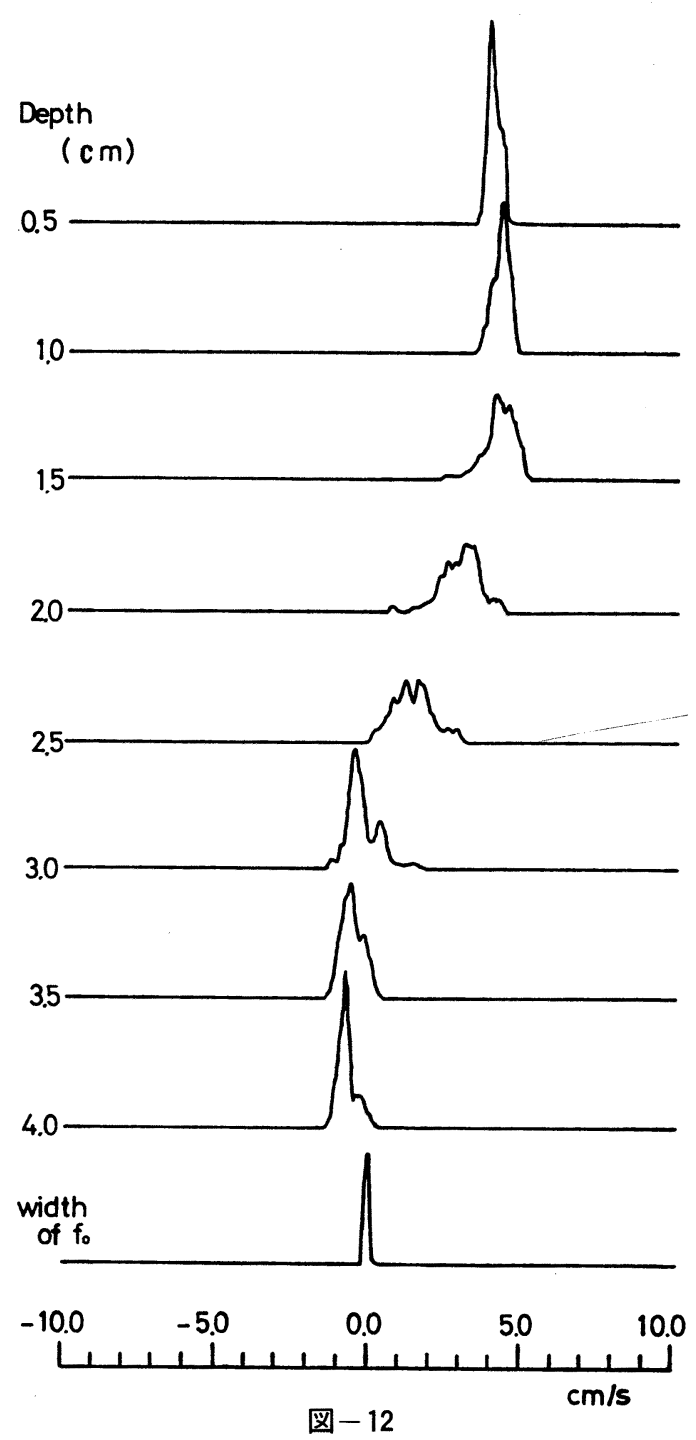

図-12 